\title{
TOXIGITY AND METABOLISM OF DRUGS IN RELATION TO DIETARY PROTEIN
}

\author{
RYUICHI KATO*, TAKAO OSHIMA** \\ AND SETSUO TOMIZAWA*** \\ * Department of Pharmacology, National Instilute of Hygienic Sciences, Setagaya-ku, Tokyo \\ ** Department of Pharmacology, School of Medicine, Keio University, Shinjuku-ku, Tokyo \\ *** Department of Pharmacology, College of Pharmaceutical Sciences, Kitasato University, Minato-ku, Tokyo
}

Received for publication April 6, 1968

It was demonstrated that the toxicities of various drugs are often related to the rate of metabolism of the drugs and to the activity of drug-metabolizing enzymes of liver microsomes (1-6). In a previous paper, it was briefly reported that the oxidation of pentobarbital, strychnine and meprobamate was markedly decreased in the immature female rats by the feeding on low protein diet or non-protein diet (7).

The purpose of present study is to investigate the effect of high and low protein diet on the toxicities of various drugs in relation to the drug-metabolizing activities of liver microsomes, and to investigate whether the alternation in the drug-metabolizing activities may be correlated to the activities of microsomal NADPH-linked electron transport system.

Since there are marked sex differences in the alternations in the activities of drugmetabolizing enzymes in the rats under some unphysiological states, the effect of diets of different protein contents on the toxicity and metabolism of drugs was comparatively investigated in male and female rats $(8-12)$.

\section{METHODS}

Male and female rats of Wistar strain, weighing about $170 \mathrm{~g}$ and $150 \mathrm{~g}$, respectively, were used. The rats were fed diets of $50 \%, 18 \%, 10 \%$ or $5 \%$ protein content for 2 weeks or fed non-protein diet for 4 days before sacrifice. The composition of the standard diet was as follows: 18\% casein, 30\% corn starch, 15\% glucose, 10\% sucrose, $10 \%$ corn oil, $10 \%$ wood pulp and salt mixture and vitamins.

The diets of various protein content were made by changing the content of casein with glucose.

The toxicities of strychnine, octamethylpyrophosphoramide (OMPA), pentobarbital and zoxazolamine were determined by the intraperitoneal injection of the drugs. The metabolism in vivo of pentobarbital was determined by measuring the rate of decrease in the concentration of pentobarbital in the serum and brain.

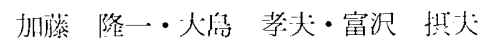

Preliminary report of this work was presented at the 23rd Annual Meeting of Pharmaceutical Society of Japan (Sendai, Oct. 1966). 
preparation of microsomes: The rats were killed by decapitation and the liver was removed, chopped into small pieces, washed well and homogenized in a Teflon-glass homogenizer with 3 volumes of ice-cold $1.15 \% \mathrm{KCl}$ solution. The homogenate was centrifuged at $9,000 \times \mathrm{g}$ for 20 minutes and the supernatant fraction was then centrifuged at $105,000 \times \mathrm{g}$ for 1 hour to sediment the microsomes.

Enzyme assays: The $9,000 \times \mathrm{g}$ supernatant $(2.5 \mathrm{ml})$ was mixed with $2.5 \mathrm{ml}$ of a solution containing NADP $(0.6 \mu$ moles $)$, glucose-6-phosphate $(20 \mu$ moles $)$, magnesium chloride $(25 \mu$ moles $)$, nicotinamide (50 $/$ moles), sodium phosphate buffer $(140 \mu$ moles, $\mathrm{pH}$ 7.4 ), potassium chloride (288 $\mu$ moles) and various substrates (2 $\mu$ mole of pentobarbital and strychnine; $1.5 \mu$ mole of zoxazolamine; $5 \mu$ mole of aminopyrine and aniline).

The mixtures were incubated in a Dubnoff-type metabolic shaker for 30 minutes at $37^{\circ} \mathrm{C}$ under air.

Oxidations of pentobarbital and strychnine were determined by measuring the disappearance of the substrates by the method of Brodie et al. and Kato et al., respectively (13, 14). Hydroxylation of aniline was determined by measuring the formation of $p$-aminophenol as described in a previous paper (15). Hydroxylation of zoxazolamine was determined by measuring the disappearance of the substrate by the method of Conney et al. (16). $\mathrm{N}$-Demethylation of aminopyrine was determined by measuring the formation of 4-aminoantipyrine as described by $\mathrm{LaDu}$ et al. (17). Microsomal NADPH oxidase was assayed by the disappearance of NADPH as described by Gillette et al. (15). Microsomal NADPHcytochrome $c$ reductase was determined by the method of Williams and Kamin (18).

Estimation of p-450, cytochrome $b_{5}$ and microsomal protein: The content of $\mathrm{p}-450$ and cytochrome $b_{5}$ was measured by difference spectrum with Hitachi automatic spectrophotometer ESP 131 as described in the previous paper (11). The amount of microsomal protein was determined by the method of Lowry et al. (19).

\section{RESULTS}

1. Effect of diets of various protein conlents on body and liver weight and liver and microsomal protein

Tables 1 and 2 show that the liver weight was greater in the rats fed high protein diet than in the rats fed low protein diets. Similarly, the content of liver microsomal protein was significantly increased in the rats fed the high protein diet and it was decreased in the rats fed the low protein diets. Thus, total liver microsomal protein was much greater in the rats fed the high protein diet than in the rats fed the low protein diets.

These results indicate that the liver weight and the content of liver microsomal protein are clearly correlated to the amount of dietary protein intake, but there is no clear sex difference.

2. Toxicities of drugs in male and female rats fed diets of various protein contents

The toxicity of strychnine $(2.4 \mathrm{mg} / \mathrm{kg}$, i.p.) was low in the male rats fed the high protein diet and it was markedly high in the male rats fed the low protein diets.

In contrast, the toxicity of OMPA $(8 \mathrm{mg} / \mathrm{kg}$, i.p. $)$ was high in the male rats fed the 
TABLE 1. Body and liver weight of rats fed diets of various protein contents.

\begin{tabular}{ccccc}
\hline $\begin{array}{c}\text { Protein content } \\
(\%)\end{array}$ & $\begin{array}{c}\text { Body weight } \\
(\mathrm{g})\end{array}$ & $\begin{array}{c}\text { Liver weight } \\
(\mathrm{g})\end{array}$ & $\begin{array}{c}\text { Liver weight } \\
\text { Body weight }\end{array} \times 100$ & $\begin{array}{c}\text { Differ. } \\
(\%)\end{array}$ \\
\hline $\begin{array}{c}\text { Male rats } \\
50\end{array}$ & $200 \pm 2$ & $9.26 \pm 0.40^{*}$ & $4.63 \pm 0.12^{*}$ & +12 \\
18 & $203 \pm 4$ & $8.14 \pm 0.38$ & $4.01 \pm 0.07$ & \\
10 & $197 \pm 3$ & $7.39 \pm 0.47$ & $3.75 \pm 0.09$ & -6 \\
5 & $181 \pm 4^{*}$ & $6.62 \pm 0.35^{*}$ & $3.66 \pm 0.12^{*}$ & -9 \\
0 & $193 \pm 3$ & $6.58 \pm 0.41^{*}$ & $3.41 \pm 0.10^{*}$ & -15 \\
\hline Female rats & & & & \\
50 & $171 \pm 5$ & $7.54 \pm 0.42^{*}$ & $4.41 \pm 0.10^{*}$ & +11 \\
18 & $170 \pm 3$ & $6.72 \pm 0.47$ & $3.95 \pm 0.09$ & -7 \\
10 & $168 \pm 4$ & $6.20 \pm 0.51$ & $3.69 \pm 0.08$ & -11 \\
5 & $160 \pm 4$ & $5.61 \pm 0.34$ & $3.51 \pm 0.09^{*}$ & -17 \\
0 & $166 \pm 3$ & $5.45 \pm 0.32^{*}$ & $3.29 \pm 0.10^{*}$ & -15 \\
\hline
\end{tabular}

The rats were fed the diets of $50 \%, 18 \%, 10 \%$ and $5 \%$ of protein content for 2 weeks or fed non-protein diet for 4 days.

Each group consisted of 12 rats and the results are expressed as average \pm standard error.

The stars in the table indicate the significant difference $(\mathrm{p}<0.05)$ from the rats fed $18 \%$ protein diet.

TABLE 2. Liver and microsomal protein of rats fed diets of various protein contents.

\begin{tabular}{ccccccc}
\hline $\begin{array}{c}\text { Protein content } \\
(\%)\end{array}$ & $\begin{array}{c}\text { Liver protein } \\
(\mathrm{mg} / \mathrm{g})\end{array}$ & $\begin{array}{c}\text { Differ. } \\
(\%)\end{array}$ & $\begin{array}{c}\text { Microsomal } \\
\text { protein } \\
(\mathrm{mg} / \mathrm{g} \text { liver })\end{array}$ & $\begin{array}{c}\text { Differ. } \\
(\%)\end{array}$ & $\begin{array}{c}\text { Microsomal } \\
\text { protein } \\
(\mathrm{mg} / 100 \mathrm{~g} \mathrm{B.W.})\end{array}$ & $\begin{array}{c}\text { Differ. } \\
(\%)\end{array}$ \\
\hline $\begin{array}{c}\text { Male rats } \\
50\end{array}$ & $179 \pm 3$ & -1 & $27.7 \pm 0.7^{*}$ & +7 & $128.3 \pm 3.7^{*}$ & +24 \\
18 & $181 \pm 2$ & & $25.9 \pm 0.5$ & & $103.9 \pm 2.9$ & -10 \\
10 & $178 \pm 3$ & -2 & $24.9 \pm 0.3$ & -4 & $93.4 \pm 1.5^{*}$ & -15 \\
5 & $165 \pm 3^{*}$ & -9 & $24.0 \pm 0.5^{*}$ & -7 & $87.8 \pm 2.1^{*}$ & -25 \\
0 & $167 \pm 2^{*}$ & -8 & $22.9 \pm 0.6^{*}$ & -12 & $78.1 \pm 3.1^{*}$ & -25 \\
\hline Female rats & & & & & & \\
50 & $180 \pm 1$ & +2 & $27.1 \pm 0.6^{*}$ & +6 & $119.5 \pm 3.4^{*}$ & +18 \\
18 & $177 \pm 2$ & & $25.6 \pm 0.4$ & & $101.1 \pm 2.5$ & -8 \\
10 & $175 \pm 2$ & -1 & $25.2 \pm 0.5$ & -2 & $93.0 \pm 2.1^{*}$ & -8 \\
5 & $167 \pm 3^{*}$ & -6 & $24.0 \pm 0.4^{*}$ & -6 & $85.7 \pm 2.3^{*}$ & -15 \\
0 & $165 \pm 2^{*}$ & -7 & $23.4 \pm 0.8^{*}$ & -9 & $77.0 \pm 4.0^{*}$ & -24 \\
\hline
\end{tabular}

See the legends for Table 1 .

high protein diet and it was markedly low in the male rats fed the low protein diets and in fact the mortality in the male rats fed the non-protein diet was zero per cent.

The toxicities of pentobarbital $(50 \mathrm{mg} / \mathrm{kg}$, i.p.) and zoxazolamine ( $140 \mathrm{mg} / \mathrm{kg}$, i.p.) were low in the male rats fed the high protein diet and they were high in the male rats fed the low protein diets (Fig. 1). Moreover, the effect of the diets of various protein contents in the toxicities of strychnine $(1.6 \mathrm{mg} / \mathrm{kg}$, i.p. $)$, OMPA $(30 \mathrm{mg} / \mathrm{kg}$, i.p. $)$, pentobarbital $(40 \mathrm{mg} / \mathrm{kg}$, i.p.) and zoxazolamine $(140 \mathrm{mg} / \mathrm{kg}$, i.p.) in the female rats was almost 


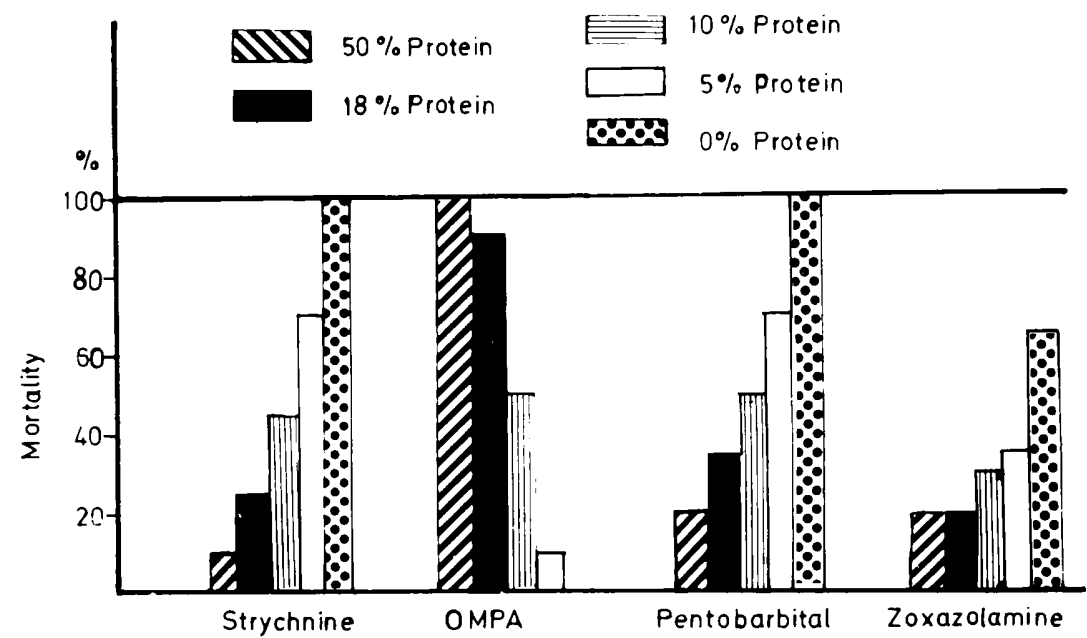

FIG. 1. Toxicity of drugs in male rats fed various protein content diets.

Four-handred male rats were fed diets of $50 \%, 18 \%, 10 \%$ and $5 \%$ of casein content for 2 weeks or fed non-protein diet for 4 days. Strychnine sulfate $(2.4$ $\mathrm{mg} / \mathrm{kg})$, OMPA (8 $\mathrm{mg} / \mathrm{kg})$, pentobarbital sodium $(50 \mathrm{mg} / \mathrm{kg})$ and zoxazolamine $(140 \mathrm{mg} / \mathrm{kg})$ were given intraperitoneally for the determination of drug toxicities.

Each group consisted of 20 rats and the results were given as the differences in percentage from the values of rats fed the $18 \%$ casein diet.

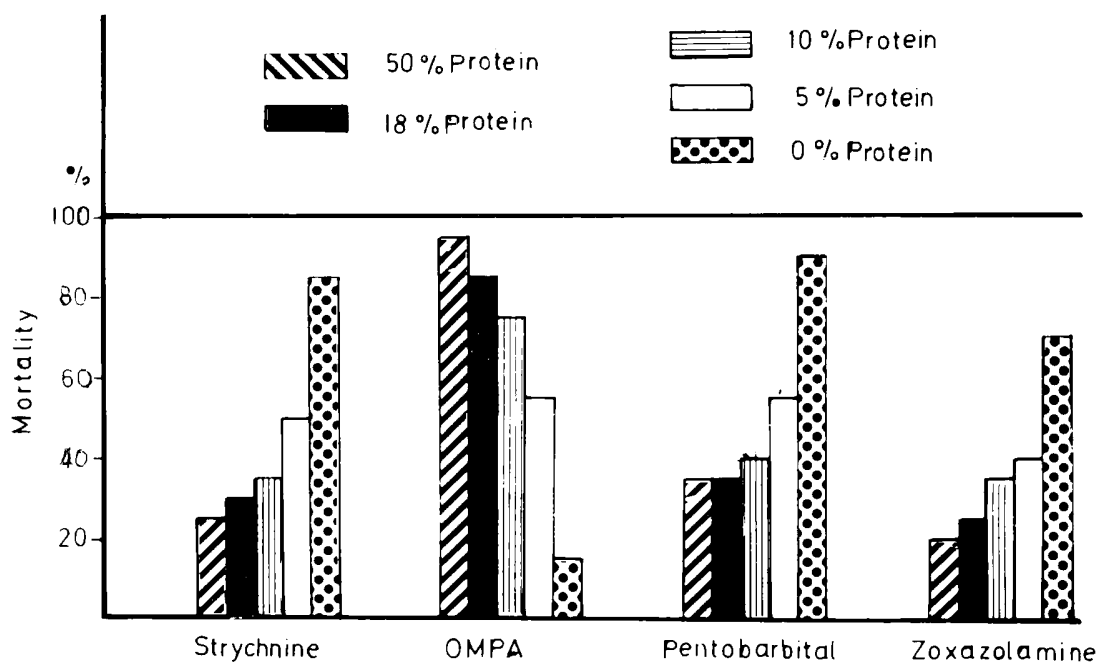

FIG. 2. Toxicity of drugs in female rats fed various protein content diets.

Four-handred female rats were fed the diets of $50 \%, 18 \%, 10 \%$ and $5 \%$ of casein content for 2 weeks or fed non-protein diet for 4 days.

Strychnine sulfate $(1.6 \mathrm{mg} / \mathrm{kg})$, OMPA $(30 \mathrm{mg} / \mathrm{kg})$, pentobarbital sodium (40 $\mathrm{mg} / \mathrm{kg})$ and zoxazolamine $(140 \mathrm{mg} / \mathrm{kg})$ were given intraperitoneally for the determination of drug toxicities.

Each group consisted of 20 rats and the results were given as the differences in percentage from the values of rats fed the $18 \%$ casein diet. 
similar to that in the male rats (Fig. 2). However, it is clearly observed from Figs. 1 and 2 that the magnitude of the differences in the toxicities of strychnine, OMPA and pentobarbital in the rats fed the diets of various protein contents was greater in the male rats than in the female rats.

\section{The metabolism in vivo of pentobarbital in male and female rats fed diets of various protein contents}

The rate of pentobarbital metabolism in the rats fed the diets of various protein contents was clearly correlated to the amount of dietary protein intake (Figs. 3 and 4). The rate of pentobarbital metabolism was the fastest in the rats fed $50 \%$ protein diets and the rate of pentobarbital metabolism was slow down correlated with the decrease in dietary protein intake. The effect of the diet of various protein contents on the rate of pentobarbital metabolism was more clear in the male rats than in the female rats.

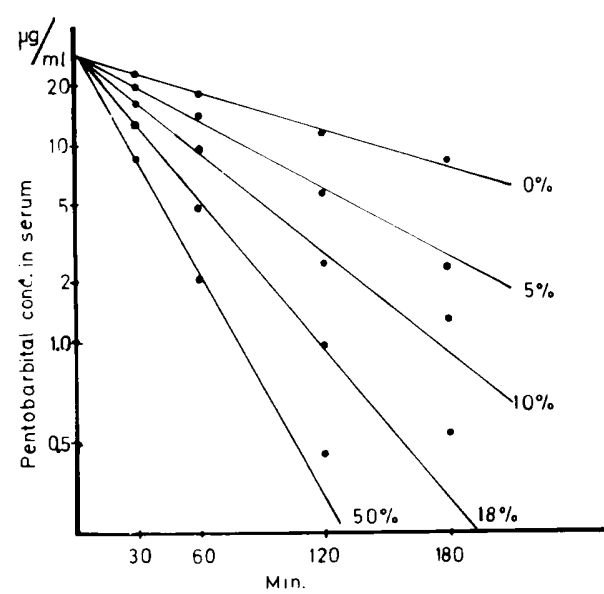

Fig. 3. The metabolism in vivo of pentobarbital in male rats fed diets of various protein contents.

One hundred twenty male rats were fed the diets of $50 \%, 18 \%, 10 \%$ and $5 \%$ of protein content for 2 weeks or fed nonprotein diet for 4 days.

Pentobarbital sodium $(30 \mathrm{mg} / \mathrm{kg})$ was given intraperitoneally and the each 6 rats were killed $30,60,120$ and 180 minutes later.

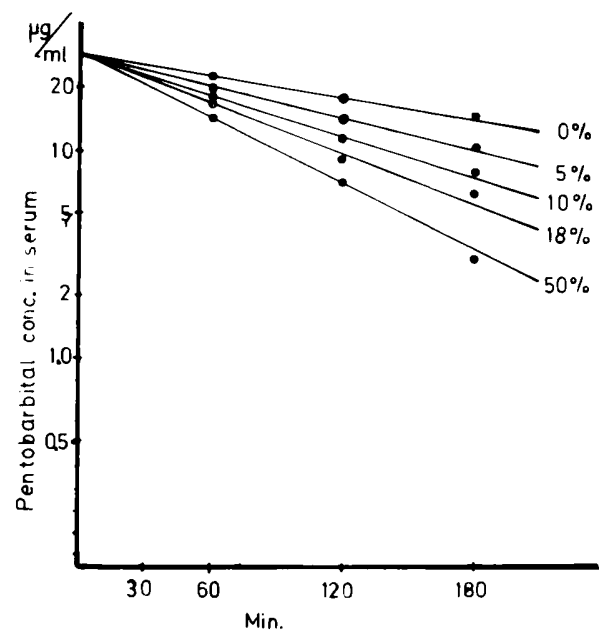

Fig. 4. The metabolism in vivo of pentobarbital in female rats fed diets of various protein contents.

Ninety female rats were fed the diets of $50 \%, 18 \%, 10 \%$ and $5 \%$ of protein content for 2 weeks or fed non-protein diet for 4 days.

Pentobarbital sodium $(30 \mathrm{mg} / \mathrm{kg})$ was given intraperitoneally and the each 6 rats were killed 60, 120 and 180 minutes later.

4. The metabolisms of pentobarbital, strychnine, aminopyrine, zoxazolamine and aniline by liver microsomes in male and female rats fed diets of various protein contents

As shown in Fig. 5 the metabolisms of pentobarbital, strychnine, aminopyrine, zoxazolamine and aniline were increased in the rats fed the high protein diet and decreased in the rats fed the low protein diets. However, the effect of the diets of various protein contents was smaller in the metabolisms of zoxazolamine and aniline than in the meta- 


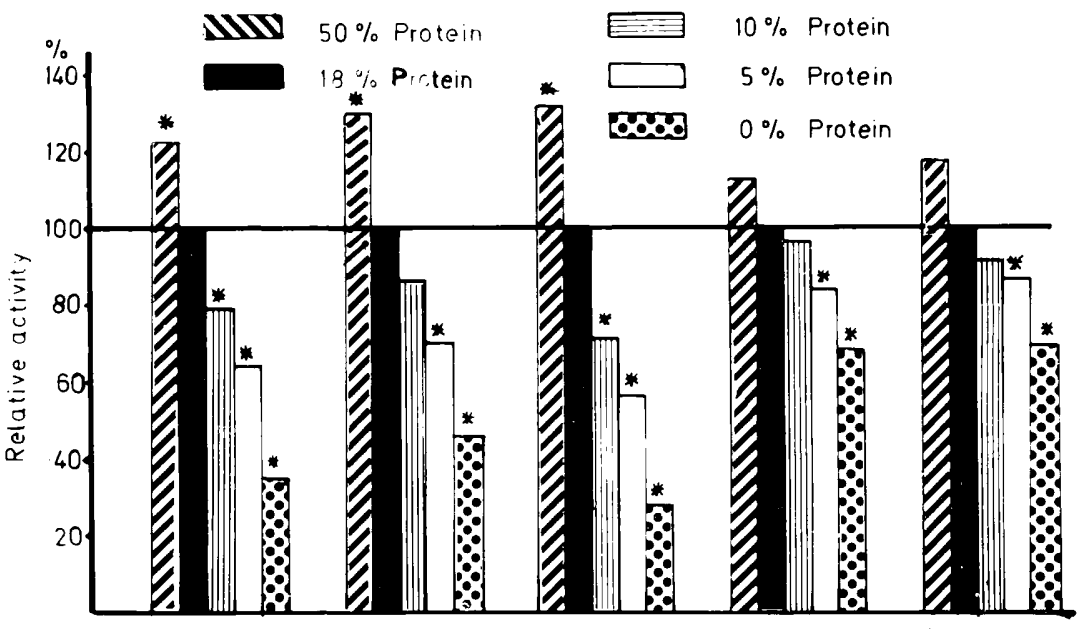

Pentobarbital Strychnine

Aminopyrine Zoxazolamine Aniline

Fig. 5. The metabolisms of pentobarbital, strychnine, aminopyrine, zoxazolamine and aniline by liver microsomes in male rats fed diets of various protein contents.

Thirty male rats were fed diets of $50 \%, 18 \%, 10 \%$ and $5 \%$ of casein content for 2 weeks or fed non-protein diet for 4 days and killed for the determination of the metabolic activities.

Each group consisted of 6 rats and the results were given as the difference in percentage from the values of the rats fed 18\% casein diet.

The activities of pentobarbital oxidation, strychnine oxidation, aminopyrine $\mathrm{N}$-demethylation, zoxazolamine hydroxylation and aniline hydroxylation in the rats fed the $18 \%$ casein dict were $19.5=1.8,24.8-1.1,17.5-2.0,12.3-0.9$ and $14.1 \div 0.8 \mathrm{~m} /$ mole $/ \mathrm{mg}$ microsomal protein $30 \mathrm{~min}$, respectively. The stars in the figure indicate significant difference $(\mathrm{p}<0.05)$ from the rats fed $18 \%$ protein diet.

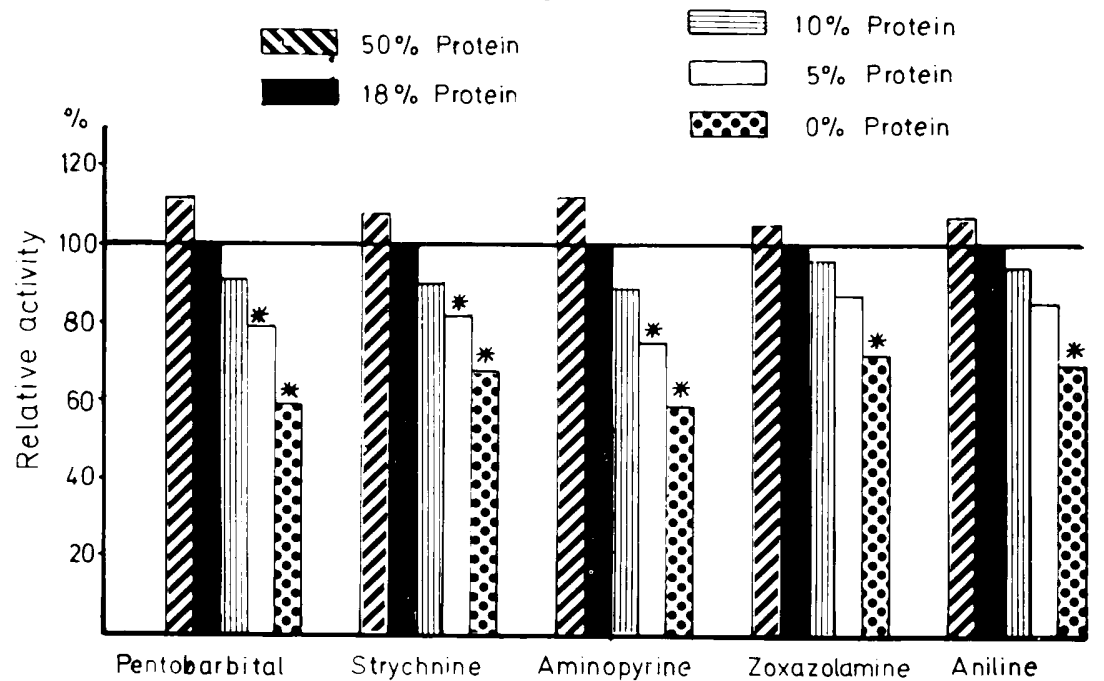

FIG. 6. The metabolisms of pentobarbital, strychnine, aminopyrine, zoxazolamine and aniline by liver microsomes in female rats fed diets of various protein contents.

Thirty female rats were fed diets of $50 \%, 18 \%, 10 \%$ and $5 \%$ of casein content for 2 weeks or fed non-protein diet for 4 days and killed the determination of the metabolic activities.

Each group consisted of 6 rats and the results were given as the difference in percentage from the values of the rats fed $18 \%$ casein diet.

The activities of pentobarbital oxidation, strychnine oxidation, aminopyrine $\mathrm{N}$-demethylation, zoxazolamine hydroxylation and aniline hydroxylation in rats fed the $18 \%$ casein diet were $6.2+0.7,7.9: 0.3,4.3: 0.4,10.0: 0.7$ and $10.2 \div$ $0.5 \mathrm{~m} /$ mole $/ \mathrm{mg}$ microsomal protein $/ 30 \mathrm{~min}$, respectively.

The stars in the figure indicate significant difference $(p<0.05)$ from the rats fed $18 \%$ protein diet. 
TABLE 3. The activities of microsomal NADPH oxidase and NADPH-cyt c reductase and the contents of cyt P-450 and $b_{5}$ in male and female rats fed diets of various protein content.

\begin{tabular}{|c|c|c|c|c|c|}
\hline & $\begin{array}{c}\text { Protein content } \\
(\%)\end{array}$ & Male rats & $\begin{array}{c}\text { Differ. }{ }^{1)} \\
(\%)\end{array}$ & Female rats & $\begin{array}{c}\text { Differ. }{ }^{1)} \\
(\%)\end{array}$ \\
\hline \multirow{5}{*}{$\begin{array}{l}\text { NADPH oxidase } \\
(\mathrm{m} \mu \mathrm{mole} / \mathrm{mg} \text { prot. } / 3 \mathrm{~min})\end{array}$} & 50 & $57.7+4.4$ & +6 & $40.0 \div 4.8$ & $\begin{array}{r}- \\
\div \quad 5\end{array}$ \\
\hline & 18 & $54.4-3.5$ & & $38.1 \div 2.1$ & \\
\hline & 10 & $52.8 \pm 3.7$ & -3 & $35.0 \pm 2.5$ & -8 \\
\hline & 5 & $43.5 \pm 2.9$ & $-20 *$ & $30.5 \pm 3.0$ & $-20 *$ \\
\hline & 0 & $38.6 \pm 4.0$ & $-29 *$ & $27.8 \div 2.0$ & $-27 *$ \\
\hline \multirow{5}{*}{$\begin{array}{l}\text { NADPH-cyt c reductase } \\
(\mathrm{m} \mu \mathrm{mole} / \mathrm{mg} \text { prot. } / 3 \mathrm{~min})\end{array}$} & 50 & $467 \pm 31$ & 4. 3 & $312 \pm 23$ & -2 \\
\hline & 18 & $453 \pm 31$ & & $318 \pm 19$ & \\
\hline & 10 & $458 \perp 25$ & +1 & $286+22$ & -10 \\
\hline & 5 & $399 \pm 27$ & -12 & $258 \doteq 23$ & -19 \\
\hline & 0 & $335 \pm 19$ & $-26^{*}$ & $232 \pm 21$ & $-27 *$ \\
\hline \multirow{5}{*}{$\begin{array}{l}\text { Cyt P-450 } \\
\text { (m/ mole/mg prot.) }\end{array}$} & 50 & $0.96 \div 0.07$ & $\div 6$ & $0.70 \pm 0.08$ & +7 \\
\hline & 18 & $0.91 \pm 0.04$ & & $0.65 \div 0.05$ & \\
\hline & 10 & $0.89 \pm 0.05$ & -2 & $0.62 \_0.07$ & -4 \\
\hline & 5 & $0.75 \pm 0.07$ & $-18^{*}$ & $0.49 \longleftarrow 0.03$ & $-24 *$ \\
\hline & 0 & $0.60 \pm 0.05$ & $-34 *$ & $0.44 \pm 0.04$ & $-33^{*}$ \\
\hline \multirow{5}{*}{$\begin{array}{l}\text { Cyt } b_{5} \\
\text { (m/tmole/mg prot.) }\end{array}$} & 50 & $0.56 \pm 0.04$ & -2 & $0.54 \pm 0.03$ & $\div 4$ \\
\hline & 18 & $0.57 \pm 0.05$ & & $0.52 \pm 0.04$ & \\
\hline & 10 & $0.56 \pm 0.02$ & -2 & $0.53 \pm 0.04$ & +2 \\
\hline & 5 & $0.52 \pm 0.04$ & -9 & $0.43 \pm 0.03$ & -18 \\
\hline & 0 & $0.46 \pm 0.03$ & $-20 *$ & $0.40 \div 0.02$ & $-24 *$ \\
\hline
\end{tabular}

Each thirty male and female rats were fed diets of $50 \%, 18 \%, 10 \%$ and $5 \%$ of casein content for 2 weeks or fed non-protein diet for 4 days and killed for the determination of electron transport activities of liver microsomes. The results were given as average - standard error from 6 rats. 1) : Difference in percentage from the values of the rats fed $18 \%$ casein diet. The stars indicate significant difference $(p<0.05)$.

bolisms of the other drugs. Moreover, the effect of the diets on the metabolisms of pentobarbital, strychnine and aminopyrine was greater in male rats than that in female rats (Fig. 6).

5. The activities of microsomal NADPH oxidase and NADPH-cyt c reductase and the contents of cyt $p-450$ and $b_{5}$ in male and female rats

The activities of microsomal NADPH oxidase and NADPH-cyt c reductase were decreased in the rats fed low or non-protein diets in both male and female rats and there was no clear sex difference in the magnitude of the decrease (Table 3).

The contents of cyt p-450 and cyt $b_{5}$ were also decreased in the rats fed low or nonprotein diets in both male and female rats. There were no clear sex difference in the magnitude of the decrease, but the decrease in the content of cyt p-450 was greater than that of cyt $b_{5}$.

6. The activities of drug-metabolizing enzymes of liver microsomes per body weight in male and female rats fed diets of various protein content

Since the liver weight of the rats fed the high protein diet was increased and that of 
TABLE 4. The activities of drug-metabolizing enzymes of liver microsomes per body weight in male and female rats fed diets of various protein contents.

\begin{tabular}{|c|c|c|c|c|c|}
\hline & $\begin{array}{l}\text { Protein content } \\
\qquad(\%)\end{array}$ & Male rats & $\begin{array}{l}\text { Differ. }{ }^{1)} \\
(\%)\end{array}$ & Female rats & $\begin{array}{l}\text { Differ. }{ }^{1)} \\
(\%)\end{array}$ \\
\hline \multirow{5}{*}{$\begin{array}{l}\text { Pentobarbital oxidation } \\
(\mu \mathrm{mole} / 100 \mathrm{~g} \text { B.W./30 min) }\end{array}$} & 50 & $3.05 \pm 0.21$ & $+50^{*}$ & $0.84 \pm 0.05$ & $+33^{*}$ \\
\hline & 18 & $2.03 \pm 0.18$ & & $0.63 \pm 0.02$ & \\
\hline & 10 & $1.43 \pm 0.10$ & $-30 *$ & $0.52 \pm 0.03$ & $-17 *$ \\
\hline & 5 & $1.09 \pm 0.10$ & $-46^{*}$ & $0.42 \pm 0.04$ & $-33^{*}$ \\
\hline & 0 & $3.54 \pm 0.11$ & $-73^{*}$ & $0.28 \pm 0.03$ & $-44^{*}$ \\
\hline \multirow{5}{*}{$\begin{array}{l}\text { Strychnine oxidation } \\
(\mu \text { mole } / 100 \mathrm{~g} \mathrm{~B} \cdot \mathrm{W} \cdot / 30 \mathrm{~min})\end{array}$} & 50 & $4.10 \pm 0.23$ & $+58 *$ & $1.02 \pm 0.07$ & $+26^{*}$ \\
\hline & 18 & $2.58 \pm 0.14$ & & $0.81 \pm 0.04$ & \\
\hline & 10 & $1.99 \pm 0.15$ & $-23 *$ & $0.66 \pm 0.03$ & -18 \\
\hline & 5 & $1.52 \pm 0.09$ & $-41 *$ & $0.55_{ \pm 0.02}$ & $-30^{*}$ \\
\hline & 0 & $0.89 \pm 0.14$ & $-65^{*}$ & $0.41 \pm 0.04$ & $-49 *$ \\
\hline \multirow{5}{*}{$\begin{array}{l}\text { Aminopyrine } \mathrm{N} \text {-demethylation } \\
(\mu \text { mole } / 100 \mathrm{~g} \text { B.W. } / 30 \mathrm{~min})\end{array}$} & 50 & $2.94 \pm 0.21$ & $+69 *$ & $0.58 \pm 0.04$ & $+32 *$ \\
\hline & 18 & $1.82 \pm 0.13$ & & $0.44 \pm 0.03$ & \\
\hline & 10 & $1.25 \pm 0.08$ & $-31 *$ & $0.36 \pm 0.03$ & -18 \\
\hline & 5 & $0.86 \pm 0.13$ & $-53^{*}$ & $0.28 \pm 0.04$ & $-36 *$ \\
\hline & 0 & $0.38 \pm 0.15$ & $-79 *$ & $0.20 \pm 0.02$ & $-54 *$ \\
\hline \multirow{5}{*}{$\begin{array}{l}\text { Zoxazolamine hydroxylation } \\
(\mu \text { mole/100 g B.W./30 min) }\end{array}$} & 50 & $1.76 \pm 0.12$ & $+38 *$ & $1.25 \pm 0.06$ & $+23 *$ \\
\hline & 18 & $1.28 \pm 0.07$ & & $1.02 \pm 0.03$ & \\
\hline & 10 & $1.10 \pm 0.05$ & -14 & $0.89 \pm 0.05$ & -13 \\
\hline & 5 & $0.91 \pm 0.04$ & $-39 *$ & $0.62 \pm 0.02$ & $-39 *$ \\
\hline & 0 & $0.65 \pm 0.05$ & $-49^{*}$ & $0.55 \pm 0.04$ & $-46^{*}$ \\
\hline \multirow{5}{*}{$\begin{array}{l}\text { Aniline hydroxylation } \\
(\mu \mathrm{mole} / 100 \mathrm{~g} \text { B.W. } / 30 \mathrm{~min})\end{array}$} & 50 & $2.10 \pm 0.09$ & $+44 *$ & $1.30 \pm 0.10$ & $+25^{*}$ \\
\hline & 18 & $1.46 \pm 0.10$ & & $1.04 \pm 0.05$ & \\
\hline & 10 & $1.20 \pm 0.11$ & -18 & $0.89 \pm 0.06$ & -14 \\
\hline & 5 & $1.07 \pm 0.05$ & $-27 *$ & $0.74 \pm 0.05$ & $-29 *$ \\
\hline & 0 & $0.76 \pm 0.05$ & $-48 *$ & $0.54 \pm 0.03$ & $-48^{*}$ \\
\hline
\end{tabular}

See the legends for Table 3 . The results were given $\mu$ mole of drugs metabolized per liver microsomes from $100 \mathrm{~g}$ body weight per 30 minutes and expressed as average $\perp$ standard error from 6 rats.

the rats fed the low protein diet was decreased, the differences in the activities of drugmetabolizing enzymes per $100 \mathrm{~g}$ body weight in the rats fed various protein diets were much clear as shown in Table 4. Thus, these differences may partially represent the differences in the rates of in vivo metabolism of drugs in the rats fed various protein diets.

\section{DISCUSSION}

It is well known that toxicities of various drugs are higher in rats fed low protein diet than in rats fed standard diet $(20,21)$.

In the present investigation it was demonstrated that the toxicities of various drugs were well correlated to the drug-metabolizing activities of liver microsomes. These results suggest that the rate of drug-metabolism by liver microsomes is likely to be a more dominant factor than the decrease in so-called general resistance to drugs for the determination of the drug toxicity in the rats fed the low protein diets. 
Indeed, since OMPA should be converted to an active metabolite by liver microsomes to manifest the toxicity (22), the results of OMPA particulary support this possibility, and recent work of McLean on the carbon tetrachloride toxicity also support this possibility. He observed that the toxicity of carbon tetrachloride in rats fed low or non-protein diets was decreased, since the activation of carbon tetrachloride to an active hepatoxic agent might be decreased in these rats $(23)$. Moreover, the liver weight to body weight ratio was greater in the rats fed the high protein diet than in the rats fed the low or nonprotein diets. These results indicate that the magnitude of the differences in the in vitro metabolism of drugs should be enhanced in the rate of in vivo metabolisms of drugs.

The presence of sex differences in the alternation of drug toxicity and drug metabolism has been often observed in the rats under unphysiological conditions $(8,10-12)$ and it is likely that the synthesis of the microsomal enzymes which are dependent on the androgen may be interfered by a protein deficiency $(10)$.

Since the activities of aniline and zoxazolamine hydroxylation are not clearly dependent on the androgen, the decrease in the activities is less than that in the pentobarbital and strychnine oxidations and aminopyrine $\mathrm{N}$-demethylation and there are no clear sex differences in the percentages of the decrease in the activities of aniline and zoxazolamine hydroxylation.

It is of interest that the activities of NADPH-linked electron transport system are decreased in the rats fed the low or non-protein diets and they are increased in the rats fed the high protein diet.

On the other hand, the administration of phenobarbital increases the liver weight, the amount of liver microsomal protein, the incorporation of amino acid into liver microsomal protein and drug-metabolizing activities and the activities of NADPH-linked electron transport system $(10,24-26)$. The effect of high protein diet, therefore, is likely similar to that of phenobarbital treatment. Moreover, the drug-metabolizing activities and the activities of NADPH-linked electron transport system in the tumor-bearing rats were decreased just as in the rats fed low protein diet and an inner protein deficiency was supposed in the tumor-bearing rats (12).

These results indicate that the drug-metabolizing activities of liver microsomes may be regulated at two steps in relation to the amount of intake of dietary protein. The first step is the activity of NADPH-linked electron transport system and the second step is the terminal oxidase activity $(11,12)$. However, the second step is strongly regulated by androgen, while the first step is only slightly regulated $(11,12,27)$.

Therefore, the regulation of the androgen-independent activities of NADPH-linked electron transport system and the terminal oxidase activities in rats fed diet of different protein contents may be exerted by some common factor(s) which is likely related to some factor(s) responsible for the regulation of the biosynthesis of microsomal protein. The regulation of the androgen-dependent activities of the terminal oxidase is strictly dependent on the amount of the intake of dietary protein as reported in the previous paper (9). 


\section{SUMMARY}

The toxicities of various drugs and the activities of drug-metabolizing enzymes and NADPH-dependent electron transport system of liver microsomes were studied in male and female rats fed diets of various protein content $(50 \%, 18 \%, 10 \%, 5 \%$ and $0 \%)$.

1. The toxicities of strychnine, pentobarbital and zoxazolamine were markedly increased in male and female rats fed the low or non-protein diets, but the magnitude of decrease was higher in the male rats than in the female rats except for zoxazolamine toxicity. The toxicities of all drugs were decreased in the rats fed the high protein diet.

2. On the other hand, the toxicity of OMPA was altered just opposite direction to these of strychnine, pentobarbital and zoxazolamine.

3. The in vivo metabolism of pentobarbital was faster in the rats fed the high protein diet and slower in the rats fed the low or non-protein diets.

4. The liver weight and the content of microsomal protein were increased in the rats fed the high protein diet and decreased in the rats fed the low or non-protein diets.

5. The metabolisms of pentobarbital, strychnine, aminopyrine, zoxazolamine and aniline by liver microsomes were decreased in the male and female rats fed the low or non-protein diets, but the magnitude of decrease in the metabolisms of pentobarbital, strychnine and aminopyrine in the male rats was greater than in the female rats.

6. The metabolisms of pentobarbital, strychnine, aminopyrine by liver microsomes were clearly increased in the male rats fed the high protein diet.

7. The activities of NADPH-linked electron transport systems were decreased in the male and female rats fed the low or non-protein diets.

8. These results indicated that the toxicities of drugs in the rats fed the high, low or nonprotein diets were closely related to the rate of drug-metabolism by liver microsomes and the activities of androgen-dependent enzymes were closely related to the amount of dietary protein intake.

9. The sex differences in the alternations of metabolic activities were discussed in relation to the magnitude of androgen-dependency.

\section{REFERENCES}

1) Conney, A.H.: Ind Internat. Pharmac. Meeling Vol. 4, p. 277 (1964)

2) Kato, R., Chiesara, E. and Frontino, G.: Biochem. Pharmac. 11, 221 (1962)

3) Kato, R., Chiesara, E. and Vassanelli, P.: This Journal 12, 26 (1962)

4) Kato, R., Chiesara, E, and Vassanelli, P.: Biochem. Pharmac. 11, 913 (1962)

5) Kato, R., Vassanelli, P. and Frontino, G.: Archs int. Pharmacody. Thér. 144, 416 (1963)

6) Kato, R., Vassanelli, P., Frontino, G. and Chiesara, E.: Biochem. Pharmac. 13, 1037 (1964)

7) Kato, R., Chiesara, E. and Vassanelli, P.: Ibid. 11, 211 (1962)

8) Kato, R. and Gillette, J.R.: J. Pharmac. exp. Ther. 150, 285 (1965)

9) Kato, R.: This Journal 16, 221 (1966)

10) Kato, R.: Ibid. 17, 181 (1967)

11) Kato, R. and Takahashi, A.: Mol. Pharmac. 4, 109 (1968) 
12) Kato, R., Takanaka, A., Takahashi, A. and Onoda, K.: This Journal 18, 224 (1968)

13) Brodie, B.B., Burns, J.J., Mark, L.C., Lief, P.A., Bernstein, E. and Papper, E.M.: J. Pharmac. exp. Ther. 109, 26 (1953)

14) Kato, R. and Takanaka, A.: This Journal in press

15) Kato, R. And Gillette, J.R.: J. Pharmac. exp. Ther. 150, 279 (1965)

16) Conney, A.H., Trousof, N. and Burns, J.J.: Ibid. 128, 333 (1960)

17) La Du, B.N., Gaudette, L., Trousof, N. and Brodie, B.B.: J. biol. Chem. 214, 741 (1955)

18) Williams, C.H. Jr. and Kamin, H.: Ibid. 237, 587 (1962)

19) Lowry, O.H., Roseborough, N.J., Farr, A.L. and Randall, R.J. : Ibid. 193, 265 (1951)

20) Drill, V.A.: Pharmac. Rev. 4, 1 (1952)

21) Rouiller, C.: The Liver, Vol. 2, p. 335, Ed. by Rouiller, C., Academic Press Inc., New York and London (1964)

22) Kato, R., Takanaka, A. and Omori, Y. : This Journal 17, 509 (1967)

23) Mclean, A.E.M. And McLean, E.K.: Biochem. J. 100, 564 (1966)

24) Remmer, H. and Merker, H.J.: Ann. N.Y. Acad. Sci. 123, 79 (1965)

25) Orrenius, S., Ericsson, J.L.E. and Ernster, L.: J. Cell. Biol. 25, 627 (1965)

26) Kato, R., Jondorf, W.R., Loeb, L.A., Ben, T. and Gelboin, H.V.: Mol. Pharmac. 2, 171 (1966)

27) Kato, R., Takanaka, A. and Takayanagi, M. : This Journal (to be published) 